\title{
Kolorektal Adenokarsinomu Taklit Eden Nonadenokarsinom Tümörlerin Retrospektif Analizi
}

Retrospective Analysis of Non-adenocarcinoma Tumors Mimicking Colorectal Adenocarcinoma Tayfun Kaya ${ }^{1}$ (D) , Ayberk Dursun $^{1}$ iD

1 Genel Cerrahi Kliniği, Sağlık Bilimleri Üniversitesi Tepecik Eğitim ve Araştırma Hastanesi, İzmir/Türkiye

\section{özeT}

AMAÇ: Kolorektal tümör (KRT) nedeniyle ameliyat edilen hastalarda en sık görülen patoloji adenokanserdir. Nonadenokarsinom KRT'ler nadirdir ve bu nedenle adenokarsinom dışı KRT’le ilgili veriler kısıtlıdır. Kliniğimizdeki nonadenokarsinom KRT'le ilgili verileri sunarak literatüre katkı sunmayı amaçlıyoruz.

GEREÇ VE YÖNTEM: Kliniğimizde 01.01.2010 - 01.01.2020 tarihleri arasında KRT nedeniyle elektif olarak ameliyat edilen hastalar retrospektif olarak tarandı. Histopatolojik olarak adenokarsinom dışı tümör tanısı konan hastalar kaydedildi.

BULGULAR: KRT nedeniyle elektif olarak ameliyat edilen toplam 798 hasta arasından adenokarsinom dışı patolojik tanısı olan 18 hasta $(\% 2,25)$ çalışmaya alındı. Dokuz hasta (\%50) kadındı ve ortalama yaş 52,8 $\pm 10,1$ idi. En sık patolojik tanı, 7 hastada (\%38,9) nöroendokrin tümör ve 4 hastada $(\% 22,2)$ lenfomaydı. Ikişer hastada $(\% 11,1)$ malign melanom ve lipom mevcuttu. Schwannoma,

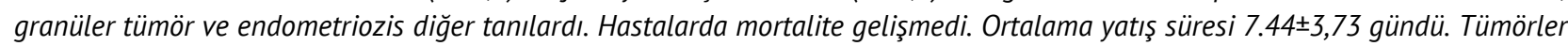
en sık rektuma (\%33,3) lokalizeydi. On iki hastada (\%66,6) 12 ve üzerinde lenf nodu eksize edildi. Tüm hastalarda cerrahi sınırlar salimdi. Ameliyat öncesi histopatolojik tanı sadece 9 hastaya (\%50) konabildi.

SONUÇ: Nonadenokarsinom KRT'ler adenokarsinomlara göre daha genç yaşlarda görülen, erkek dominansı olmayan, ameliyat öncesi tanı oranı düşük nadir tümörlerdir. Kolorektal cerrahlar, ameliyat öncesi tanı konulamayan, atipik özellikleri olan tümöral kitlelerde adenokarsinom dışı tümörleri akılda tutmalıdır. Tanı ve tedavi sürecinde multidisipliner yaklaşım önemlidir.

Anahtar Kelimeler: kolorektal kanser, kolorektal tümörler, adenokarsinom, nöroendokrin tümör, kolonik lenfoma

\section{ABSTRACT}

OBJECTIVE: Adenocarcinoma is the most common pathology in patients operated on for colorectal tumor (CRT). Nonadenocarcinoma CRTs are rare and therefore data on non-adenocarcinoma CRT are limited. We aim to contribute to the literature by presenting data on non-adenocarcinoma CRT in our clinic.

MATERIALS AND METHODS: Patients who underwent elective surgery due to CRC in our clinic between 01.01.2010 and 01.01.2020 were retrospectively screened. Patients who were diagnosed histopathologically as non-adenocarcinoma tumor were recorded.

RESULTS: Eighteen patients (2.25\%) with a pathological diagnosis other than adenocarcinoma among 798 patients who were operated electively for CRC were included in the study. Nine patients were female (50\%) and the mean age was 52.8 $\pm 10,1$. The most common pathological diagnosis was neuroendocrine tumor in 7 patients (38.9\%) and lymphoma in 4 patients (22.2\%). Two patients (11.1\%) had malignant melanoma and lipoma. Schwannoma, granular tumor, and endometriosis were other diagnoses. No mortality developed in the patients. Mean hospital stay was $7.44 \pm 3,73$ days. Tumors were most frequently localized to rectum (\%33,3). In 12 patients (66.6\%), 12 or more lymph nodes were excised. Surgical margins were safe in all patients. Preoperative histopathological diagnosis could only be made in 9 patients (50\%).

CONCLUSION: Non-adenocarcinoma CRT are rare tumors that are seen at younger ages than adenocarcinomas, do not have male dominance and have a low preoperative diagnosis rate. Colorectal surgeons should keep in mind non-adenocarcinoma tumors in tumoral masses with atypical features that cannot be diagnosed before surgery. Multidisciplinary approach is important in the diagnosis and treatment process.

Keywords: colorectal cancer, colorectal tumors, adenocarcinoma, neuroendocrine tumor, colonic lymphoma

Yazışma Adresi/Address for Correspondence: Tayfun Kaya, MD, S.B.Ü. Tepecik Eğitim ve Araştırma Hastanesi Güney Mahallesi, 1140/1. Sk. No:1, 35180

Yenişehir/Konak/İzmir/Türkiye

E-Posta/E-Mail: kayatayfun@yahoo.com || Tel: +905065094578

Received/Geliş Tarihi: 28.10.2020 || Accepted/Kabul Tarihi: 29.12.2020

Bu Eser Creative Commons Atıf-Gayriticari 4.0 Uluslararası Lisansı İle Lisanslanmıştır. This work is licensed under a Creative Commons

Attribution-NonCommercial 4.0 International License (CC BY-NC 4.0). 


\section{GiRiş}

Kolorektal kanser (KRK) Amerika Birleşik Devletleri'nde $(A B D)$ en sık teşhis edilen dördüncü kanserdir ve kansere bağlı ölümlerinin en sık ikinci nedenidir (1). Türkiye Halk Sağlığı Genel Müdürlüğü'nün 2014 yılı verilerine göre, KRK'ler kadınlarda ve erkeklerde en sık görülen üçüncü kanser türüdür. Erkeklerde yüz binde 22.8 ve kadınlarda ise yüz binde 13.8 sıklığında meydana gelir (2). Histopatolojik olarak en sık görülen alt tipi adenokarsinomdur. Nonadenokarsinom kolorektal tümörler (KRT) ise son derece nadir görülmektedir. Kore Ulusal Kanser Kayıt Merkezinin verileri kullanarak yapılan, 267.142 hastanın dahil edildiği bir çalışmada nonadenokarsinom KRT'lerin oranı \%5,43'tür (3). Literatür incelendiğinde geniş hasta serilerini içeren veriler kısıtıdır. Günümüzde erken tanı oranlarının artmasıyla beraber KRK'ye bağı ameliyatlar artmakta, buna bağı olarak da daha fazla nonadenokarsinom tümor tanısı almaktadır. Tek merkezde ameliyat edilen, nonadenokarsinom kolorektal tümörü olan 18 hastanın verileri literatür eşliğinde sunuluyor.

\section{GEREÇ VE YÖNTEM}

Tepecik Eğitim ve Araştırma Hastanesi genel cerrahi kliniğinde, 01.01.2010 ve 01.01.2020 tarihleri arasında KRT nedeniyle elektif olarak ameliyat edilen hastaların verileri retrospektif olarak tarandı. Histopatolojik olarak nonadenokarsinom tümör tanısı alan hastalar çalışmaya dahil edildi. Acil nedenlerle ameliyat edilenler, 18 yaş altı hastalar ve elektronik ortamda verilerine tam olarak ulaşılamayan hastalar çalışmaya dahil edilmedi. Hastaların demografik özellikleri, ameliyat öncesi karsinoembriyojenik antijen (CEA) değeri, ortalama hastane yatış süresi, gelişen mortalite ve morbidite, tümörün lokalizasyonu ve boyutu, uygulanan cerrahi prosedür, tümörün histopatolojik tipi, tümörün patolojik $T$ evresi, eksize edilen toplam ve metastatik lenf nodu sayısı gibi veriler kaydedildi. Çalışmanın yerel etik kurul onayl; Sağlık Bilimleri Üniversitesi Tepecik Eğitim ve Araştırma Hastanesi Girişimsel Olmayan Araştırmalar Etik Kurulu'ndan 12.10.2020 tarih ve 2020/12-29 karar numarası ile alınmıştır.

\section{BULGULAR}

Elektif KRT ameliyatı uygulanan 798 hastanın, 18'inde $(\% 2,25)$ adenokarsinom dışı tümör vardı. Cinsiyete göre dağılımda fark yoktu ve hastaların 9'u erkek (\%50), 9'u kadındı (\%50). İleri yaşta görülen adenokarsinomların aksine, nonadenokarsinomların ortalama görülme yaşı 52,8'di (33-70) ve hastaların 8'i (\%44,4) 50 yaşın altındaydı. Tümör lokalizasyonları incelendiğinde, en sık sırasıyla 6 hastada $(\% 33,3)$ rektumda ve 4 hastada $(\% 22,2)$ çıkan kolonda tümör mevcuttu (Tablo 1). Histopatolojik tiplere göre, en sık görülen nonadenokarsinom tümör tipi 7 hastada saptanan nöroendokrin tümördü (NET) (Tablo 2).

Tablo 1. Tümör Lokalizasyonları

\begin{tabular}{|ccc|}
\hline Yerleşim Yeri & Toplam hasta sayısı & $\%$ \\
Rektum & 6 & 33,3 \\
Çıkan kolon & 4 & 22,2 \\
Çekum & 2 & 11,1 \\
Sigmoid kolon & 2 & 11,1 \\
Transvers kolon & 1 & 5,55 \\
Inen kolon & 1 & 5,55 \\
Apendiks & 1 & 5,55 \\
Multipl yerleşim & 1 & 5,55 \\
Toplam & 18 & 100 \\
\hline
\end{tabular}

Tablo 2. Histopatolojik alt tiplerin dağılımı, cinsiyet ve lokalizasyon verileri

\begin{tabular}{|c|c|c|c|c|c|c|}
\hline \multirow{2}{*}{$\begin{array}{l}\text { Histopatolojik Alt } \\
\text { Tipler }\end{array}$} & \multirow[t]{2}{*}{$n$} & \multirow{2}{*}{$\begin{array}{l}\mathrm{n} \\
\%\end{array}$} & \multicolumn{2}{|c|}{ Cinsiyet } & \multirow{2}{*}{$\begin{array}{c}\text { En sık } \\
\text { lokalizasyon }\end{array}$} & \multirow[t]{2}{*}{$\mathrm{n}$} \\
\hline & & & K & E & & \\
\hline Nöroendokrin TM & 7 & 38,9 & 5 & 2 & Rektum & 4 \\
\hline Lenfoma & 4 & 22,2 & 0 & 4 & Çıkan kolon & 2 \\
\hline \multirow[t]{2}{*}{ Lipom } & 2 & 11,1 & 2 & 2 & $\begin{array}{l}\text { Sigmoid } \\
\text { kolon }\end{array}$ & 1 \\
\hline & & & & & $\begin{array}{l}\text { Transvers } \\
\text { kolon }\end{array}$ & 1 \\
\hline Malign Melonom & 2 & 11,1 & 2 & 0 & Rektum & 2 \\
\hline Schwannoma & 1 & 5,55 & 1 & 0 & Çekum & 1 \\
\hline Endometriozis & 1 & 5,55 & 1 & 0 & $\begin{array}{l}\text { Sigmoid } \\
\text { kolon }\end{array}$ & 1 \\
\hline $\begin{array}{r}\text { Granüler Hücreli } \\
\text { TM }\end{array}$ & 1 & 5,55 & 0 & 1 & $\begin{array}{l}\text { Multipl } \\
\text { yerleşim }\end{array}$ & 1 \\
\hline Toplam & 18 & 100 & 9 & 9 & & \\
\hline
\end{tabular}

n: Toplam hasta sayısı, K: kadın E: erkek TM: tümör

NET, bu 7 hastanın 4'ünde $(\% 57,1)$ rektumda, 2'sinde çıkan kolonda ve 1'inde appendikste yerleşmişti. NET görülen hastaların ortalama yaşı 53,2 idi ve bu hastaların 5'i kadındı. NET'lerin örneklerinin patolojik evrelemesi incelendiğinde 2 hastada grade 2, 5 hastada grade 3 tümör mevcuttu. İkinci en sık nonadenokarsinom tümör tipi lenfomaydı ve 4 hastada $(\% 22,2)$ saptandı. Bu hastaların 3'ünde tümör çıkan kolon yerleşimliydi. Şekil 1'de çekum yerleşimli kolonik lenfoma hastasına ait bilgisayarlı tomografi görüntüsü verilmiştir. Lenfoma saptanan tüm hastalar erkekti ve

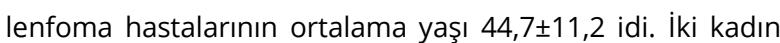
hastaya malign melanom, 2 erkek hastaya da lipom tanısı kondu. Sigmoid kolonda lipom olgusuna ait bilgisayarlı tomografi görüntüsü Şekil 2'dedir. Çalışmamızdaki diğer nonadenokarsinom tümörler ise endometriozis, 
schwannoma ve granüler hücreli tümördü ve 1'er hastada görüldüler. NET tanılı hastanın histopatolojik görüntüsü Şekil 3'te verilmiştir.

Şekil 1. Çekum yerleşimli kolonik lenfoma, bilgisayarlı tomografi, aksiyel kesit (kırmızı ok)

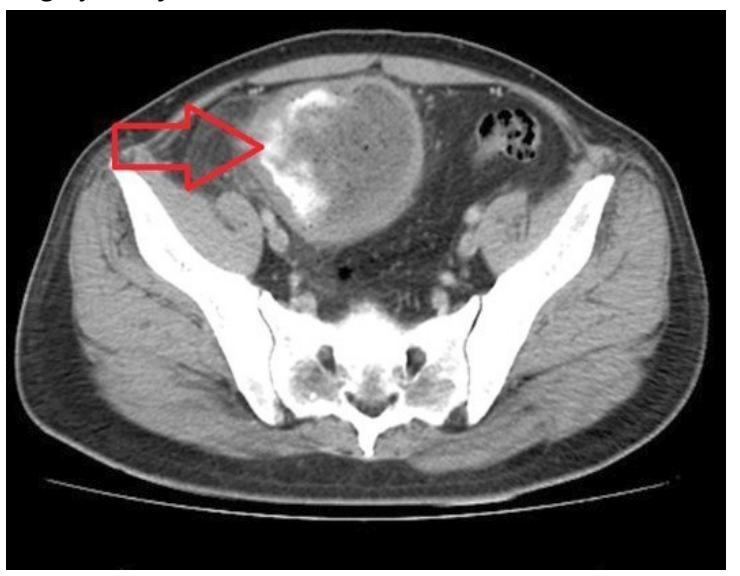

Ameliyat öncesinde hastaların yarısına tanı konulabildi. NET tanılı 7 hastanın 3'ü, lenfoma tanılı 4 hastanın 3'ü, kolorektal lipom tanılı 2 hasta tanı konulamayan grupta idi. Malign melanomlu iki hastaya kolonoskopik biyopsi ile ameliyat öncesi histopatolojik tanı konulmuştu (Şekil 4). Sayı olarak 12 ve üzerinde lenf nodu diseke edilen hasta sayısı; 12 idi $(\% 66,6)$. Ameliyat öncesinde tanı konulan ve konulamayan hastalar kıyaslandığında, her iki grupta da 12 ve üzerinde lenf nodu diseke edilen hastaların sayısı eşittir. Nihai patoloji raporları incelendiğinde; lenf nodu diseksiyonu yapılan 6 NET tanılı hastanın 5'inde (\%83,3), lenfoma tanılı 4 hastanın 2'sinde (\%50), malign melanoma tanılı 2 hastanın 2'sinde (\%100) lenf nodlarında metastaz saptandığı görüldü. Tüm hastaların ortalama tümör boyutu; $6,47 \pm 4,08$ cm'dir. Patolojik incelemede sonucunda hastalarda cerrahi sınırlar salimdi ve hiçbir hastaya ek rezeksiyon gereksinimi olmadı.

Şekil 2. Sigmoid kolon yerleşimli kolonik lipom, bilgisayarlı tomografi, koronal kesit (kırmızı ok)

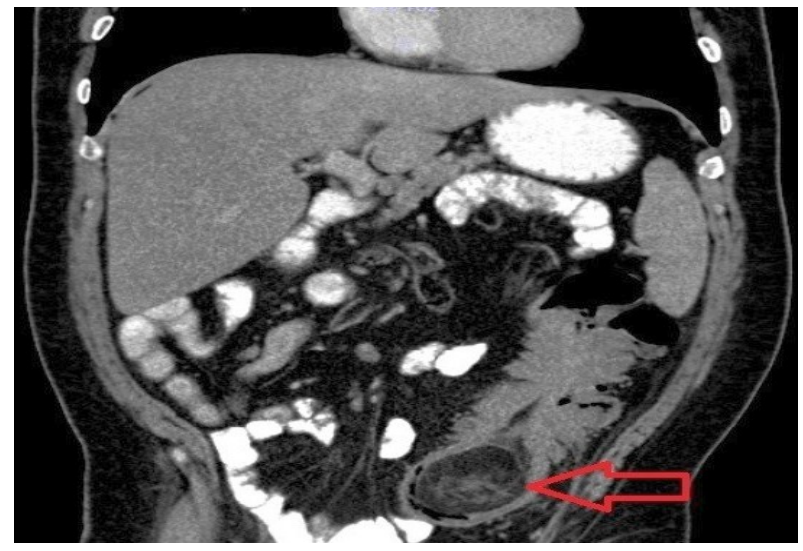

Şekil 3. Nöroendokrin tümöre (NET) ait histopatolojik mikroskopi görüntüsü. A. Kolon mukozasında solid yuvalanma gösteren monoton tümör hücreleri (HE, 10x) B. NET hücrelerinde yaygın sinaptofizin pozitifliği (DAB, 10x)

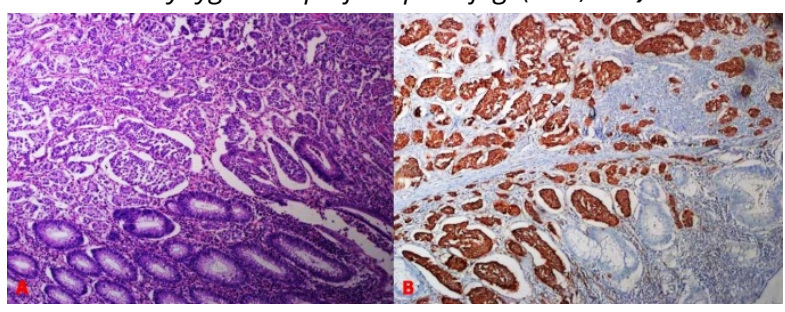

Şekil 4. Malign melanom (MM) ait histopatolojik mikroskop görüntüsü. A. Kolon mukozası altında pleomorfik tümör hücreleri (HE, 10x) B. MM hücrelerinde HMB45 pozitifliği (DAB, 20x)

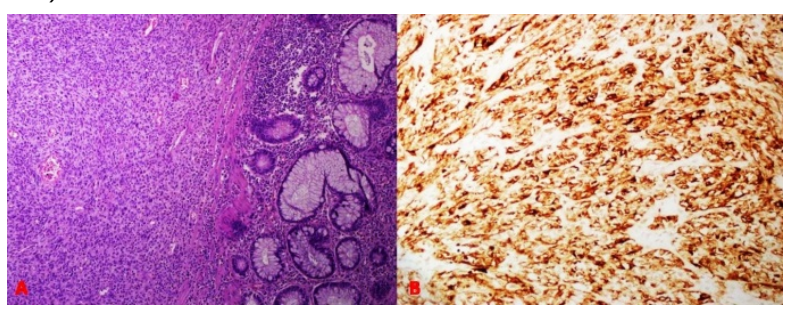

Morbidite olarak hastalarda en sık sırasıyla; 3 hastada $(\% 16,6)$ cerrahi alan enfeksiyonu ve 2 hastada $(\% 11,1)$ pnömoni meydana geldi. Hiçbir hastada perioperatif 30 günlük mortalite gelişmedi. Tüm hastaların hastanede ortalama yatış süresi 7,44 gün olarak hesaplandı. Tümör alt tiplerine göre genel sağ kalımlar incelendiğinde NET tanılı hastalarda: grade 1 ve 2 tümörlerde 3 yıllık genel sağkalım $\% 100$, grade 3 tümörlerde $\% 60$ 'tır. Beş yıldır takipli olan, grade 3 tümörlü 4 hastanın genel sağkalım oranıysa \%50'dir. Lenfoma tanılı hastalarda 3 yıllık genel sağkalım \%100, 5 yıllık takip süresini dolduran 3 hastada da yine \%100'dür. Malign melanom tanısı konan 2 kadın hastanın sağkalım süreleri 5 ay ve 25 ay idi. Ameliyat öncesi CEA değeri $\geq 5 \mathrm{ng} / \mathrm{ml}$ olan iki hasta vardı ve hastaların ikisi de NET tanısı aldı. Cerrahi prosedürler arasında, çekum, çıkan kolon ve apendiks kaynaklı tümörler sayıca fazla olduğu için, en sık sağ hemikolektomi tercih edildi.

\section{TARTIŞMA}

KRK, dünyada en sık tanı konulan üçüncü kanser türüdür (4). Dünya Sağlık Örgütü GLOBOCAN 2018 verilerine göre, insidans bakımından üçüncü, mortalite açısından ikinci sırada yer alır (5). En sık görülen alt tipi adenokarsinom olup, erkeklerde kadınlara göre daha sıktır ve 50 yaş üzerinde her iki cinsiyette de sıklığı artmaktadır. Kolorektal adenokarsinomun gelişmesinin temelinde adenomkarsinom sekansı yer alır ve altta yatan moleküler ve 
biyolojik süreçler büyük ölçüde tanımlanmıştır (6). Adenokarsinomların aksine nonadenokarsinom tümörler daha az sıklıkta görülür ve literatürde yer alan bilgiler kısıtlıdır.

Yeni Zelanda Kanser Kayıt Merkezi'nin verileri kullanılarak yapılan, 6,387 KRK hastasının incelendiği bir çalışmada nonadenokarsinom tümörlerin oranı sadece \%3'tür (7). Kore'de yapılan, çok geniş hasta serilerini içeren ulusal çalışmada bu oran \%5,43 olarak yayımlanmıştır (3). Türkiye'de Çalışkan ve ark. yaptığı tek merkezli çalışmada adenokarsinom dışı patolojilerin oranı \%4,24'tür (8). Bu çalışmalarda elektif ve acil cerrahi ayrımı yapılmamış olup, sadece elektif KRT ameliyatlarının alındığı bizim çalışmamızda ise bu oran \% 2,25 olarak bulunmuştur.

NET, en sık ince bağırsak ve apendikste görülür (9). Kolorektal yerleşimli NET nadirdir ve tüm kolorektal malignitelerin \% 2'sinden azını oluşturur (10). Kolorektal NET, adenokarsinomlarla benzer olarak ileri yaşta daha sık görülür. Kadınlarda erkeklere göre $\% 80$ oranında daha sıktır. Appendiks dışı yerleşen NET sırasıyla en sık çıkan kolon, çekum ve rektuma yerleşim gösterir $(3,11)$. Bizim hasta grubumuzda da benzer olarak, 7 hastanın $5^{\prime} i$ kadındı $(\% 71,4)$ ve ortalama yaş $53,2 \pm 6,1$ bulundu. Tümör hastaların 4'ünde rektum, 2'sinde çıkan kolon, 1'inde appendiks yerleşimliydi. Verilerimizde, lokalizasyon olarak rektumun appendikse göre daha sık görülmesi literatürle çelişkili gibi görünmesine rağmen, bu çalışmaya acil ameliyatlar dahil edilmemiştir. Bu nedenle akut appandisit nedeniyle ameliyat edilip appendisial NET tanısı konulan hastalar çalışmamızda yer almamıştır. Preoperatif dönemde histopatolojik olarak NET tanısı konulma oranı düşüktür ve Maryanski ve ark. 15 hastanın 4'üne $(\% 26,6)$ preoperatif olarak kesin tanı konduğunu açıklamıştır (11). Bizim çalışmamızda bu oran 7 hastada 4 'tür $(\% 57,1)$. Kolorektal NET tanı anında genellikle bölgesel lenf nodlarına metastaz yapar (12). Bu nedenle cerrahi tedavide, endoskopik rezeksiyon yapılabilen $<1 \mathrm{~cm}$ ve yüzeyel yayılımlı tümörler dışındakilere segmental rezeksiyon ve bölgesel lenf nodu diseksiyonu uygulanır (13). Bizim serimizde grade-2 NET'i olan ve tümör boyutu $<1 \mathrm{~cm}$ olması nedeniyle trans anal eksizyon yapılan hasta dışındaki, çevresel lenf nodu diseksiyonu yapılan diğer 6 hastanın 5 'inde $(\% 83,3)$ lenf nodu metastazı saptandı. Ameliyat sonrasında tüm NET tanılı hastalara multidisipliner onkoloji konseyinde kemoterapi verilmesi kararı alındı.
Ekstranodal lenfomalar en sık gastrointestinal sistemde (GiS) görülür. Bununla birlikte primer kolorektal lenfomalar (KRL), GiS lenfomalarının en az görülenidir ve tüm bağırsak malignitelerinin <\%1'ini oluşturur (14). Gay ve ark.'nın yaptığı bir derleme çalışmasında, erkeklerde daha sık görülmektedir. KRL tedavisinde cerrahi rezeksiyon ön planda olmakla birlikte tedaviye rehberlik edecek kesin veriler yoktur ve bu nedenle tedavide birçok farklı branşın multidisipliner yaklaşımı önerilmektedir (14). Kolorektal lenfomalarla ilgili literatürde yer alan yayınlar tek merkezlidir ve hasta sayıları bakımından son derece kısıtlıdır. Iwamuro ve ark.'nın çalışmasında 12 hasta incelenmiş; hastaların 7'si kadın, 5'i erkektir ve ortalama görülme yaşı 58,7'dir (15). Üçüncü basamak bir hastanede, 10 yıllık verilerin retrospektif olarak incelendiği bir çalışmaya 18 primer kolorektal lenfomalı hasta dahil edilebilmiş, tek değişkenli analizde sağkalım ile ilişkili tek faktör cerrahi rezeksiyon ve ardından kemoterapi tedavisi olarak bulunmuştur. Söz konusu çalışmada, hastaların 10'u erkek, ortalama görülme yaşı 57, en sık lokalizasyon çekumdur (16). Ünal ve ark. KRL oranını \%0,5 olarak bulmuştur (17). Bizim serimizdeki KRL'li 4 hastanın tüm KRT'lere oranı da benzer olarak \%0,5'tir ve ilginç olarak 4 hasta da erkektir. Ortalama görülme yaşları 44,7 olarak bulunmuştur ve 2 hastada çıkan kolonda, 1 hastada da çekumda lokalizedir (Şekil 1). Hastalarımızın hepsine cerrahi rezeksiyon uygulanmış, hematolog ve onkologların olduğu multidisipliner konseyde değerlendirilerek tüm hastalara kemoterapi tedavisi verilmiştir. Dört hastanın 2'sinde lenf nodu metastazı saptanmıştır. Hastaların 3 yıllık sağkalımı $\% 100,5$ yıllık takip süresini tamamlayan 3 hastanın da sağkalım oranı \%100'dür.

Kolorektal malign melanomlar (KMM) sıklıkla kadınlarda meydana gelmektedir ve prognozu kötüdür. Tedavisi cerrahidir. Atak yayınladığı çalışmasında, 6 hastanın 4'ünü kadın ve ortalama sağkalım süresini 12,5 ay olarak bildirmiştir (18). Sıklıkla rektumda meydan gelmektedir. (3). Ünal ve ark. Ege Üniversitesi'nde yaptığı 7.285 KRK hastasının sonuçlarının verildiği bir çalışmada KMM sıklığı $\% 0,3$ olarak bulunmuştur (17) Bizim serimizde KMM görülme oranı \%0,25'tir. İki hastamız da kadındı, iki hastaya da abdominoperineal rezeksiyon uygulandı ve bir hastada lenf nodu metastazı saptandı. Ortalama sağkalım süresi 14,5 aydı. 
Kolon lipomları, submukozal yerleşimli, çoğunlukla asemptomatik ve cerrahi tedavi gerektirmeyen tümörlerdir. Ancak 2 cm'den büyük lipomlar semptomatik olabilirler (19). Bizim serimizde toplam 2 hasta kolorektal lipom nedeniyle ameliyat edilmişti ve ikisi de erkekti. İki hastada da parsiyel obstrüksiyon yaratan, tanı konamayan kitle nedeniyle elektif ameliyat planlandı ve tümör boyutları sırasıyla 11,5 $\mathrm{cm}$ ve $3 \mathrm{~cm}$ 'di.

Kolorektal schwannoma, ileri yaşlarda ortaya çıkan, kadın ve erkeklerde eşit olarak görülen, gastrointestinal schwannomanın çok nadir bir alt tipidir. Çoğu zaman tesadüfi olarak kolonoskopide submukozal kitle olarak tespit edilirler ve kesin tanı rezeksiyon materyalinin patolojik incelemesinde konulur (20). Bizim çalışmamızda yer alan tek schwannoma vakası, 53 yaşında kadın hastaydı ve karın ağrısı nedeniyle yapılan rutin kolonoskopide çekumda tespit edilen dev submukozal kitle nedeniyle ameliyat edilmişti. Kesin tanı nihai patolojik inceleme ile konuldu ve tümör boyutu $12 \mathrm{~cm}$ ölçüldü. Ameliyat sonrası ek tedavi verilmedi.

Kolorektal endometriozis, üreme çağındaki kadınlarda görülen ve ameliyat öncesi tanı konamaması nedeniyle kolorektal adenokanserle sıklıkla karıştırılan bir hastalıktır. En sık rektosigmod kolonda görülür (21). Cerrahi tedavide, KRK ayırıcı tanısı yapabilme, doğurganlığı koruma ve cerrahi stresi önleme gibi nedenlerle laparoskopik yaklaşım önerilir (22). Endometriozisin medikal tedavisinde yüksek doz progesteron, GnRH agonistleri ve danazol önerilir. Serimizde yer alan 38 yaşında kadın hastaya uzun süredir devam eden karın ağrısı nedeniyle kolonoskopi uygulandı ve rektosigmoid bileşkede lümeni daraltan submukozal kitle lezyonu nedeniyle laparaskopik low anterior rezeksiyon uygulanarak endometriozis tanısı konuldu. Ameliyat sonrası kadın doğuma konsülte edilen hastaya yüksek doz progesteron tedavisi verildi. Semptomları tamamen gerileyen hasta, 2 yıldır nükssüz olarak takip ediliyor.

Granüler hücreli tümörler, malign potansiyeli olan, asemptomatik seyreden bir mezenkimal tümördür ve kolonoskopide submukozal kitle olarak görünür, fakat endoskopik ve immünohistokimyasal tekniklerin geliştirilmesi nedeniyle tanı ve tedavi oranları giderek artmaktadır (23). Biz de serimizde yer alan tek hastaya kolonoskopik olarak preopatif tanı konulduktan sonra elektif olarak ameliyat planladık. Hastaya multipl kolonik yerleşim nedeniyle subtotal kolektomi ve ileorektal anastomoz uygulandı ve hastanın 1 yıllık takibinde nüks görülmedi.

KRK tanısı ve takibinde tüm tartışmalara rağmen CEA popülerliğini korumaya devam etmektedir. Birçok rehberde CEA'nin tanıdan ziyade takipteki önemi vurgulanmaktadır. intilaflı olmakla birlikte kliniklerdeki rutin pratikte kolorektal adenokanser tanısında CEA cut-off değeri olarak $>5 \mathrm{ng} / \mathrm{ml}$ anlamlı kabul edilebilir ve bu bazı çalışmalarda da vurgulanmıştır (24). Nonadenokarsinom KRK'de ise kullanımı kısıtlıdır. Bizim çalışmamıza dahil edilen ve ameliyat öncesi kesin tanı konamayan 9 hastadan da ameliyat öncesi tanı sürecinde CEA düzeyi ölçülmüş ve 7 hastada $<5 \mathrm{ng} / \mathrm{ml}$, postoperatif NET tanısı konan 2 hastada $>5 \mathrm{ng} / \mathrm{ml}(18,29 \mathrm{ng} / \mathrm{ml}$ ve $6,25 \mathrm{ng} / \mathrm{ml})$ olarak bulunmuştur.

Sonuç olarak, nonadenokarsinom kolorektal tümörler adenokarsinomlara kıyasla son derece nadir görülen, kolonoskopik tekniklerin ve histopatolojik teknolojinin gelişmesi ile giderek daha çok tanı konulan bir klinik antitedir. Erkek popülasyonda ve ileri yaştaki hastalarda daha baskın görülen adenokarsinomların aksine cinsiyet açısından daha homojen dağılım göstermektedir ve daha genç yaş grubunda ortaya çıkmaktadır. Bu nedenle kolorektal cerrahların rutin pratiğinde giderek daha çok karşılaştığı ve her biri kendi içinde farklı tanı, tedavi ve takip prensipleri içeren hastalıklar grubudur. Biz kendi verilerimizi sunarak kısıtlı literatüre katkı sağlamayı amaçladık. Bu hastaların tanı, tedavi ve takibinin temelinde, preoperatif ve postoperatif süreçte cerrahların, hematologların, onkologların ve gastroenterologların yer aldığı multidisipliner yaklaşımın yer almasını öneriyoruz. Atipik özellikleri olan ve kesin tanı konamayan kolorektal yerleşimli kitlelerde, bu özel ve nadir hastalıklar her zaman düşünülmelidir.

Etik: Bu çalışmanın etik kurulu alınmıştır (12.10.2020 tarih ve 2020/12-29).

Ethics committee approval had been taken $(12.10 .2020$ 2020/12-29).

Yazar katkı durumu; Çalışmanın konsepti; TK, dizaynı; TK, AD, Literatür taraması; TK, $A D$, verilerin toplanması ve işlenmesi; $T K, A D$ Istatistik; $A D$, yazım aşaması; TK, $A D$

Author contribution status; The concept of the study; TK design; $T K, A D$ literature review; $T K, A D$, collecting and processing data; $T K, A D$ statistics; $A D$ writing phase; $T K, A D$

Yazarlar arasında çıkar çatışması yoktur. 


The author declares no conflict of interest.
Finansal Destek: yoktur / Funding: none
doi: https://doi.org/10.33713/egetbd.817721

\section{KAYNAKLAR}

1. Provenzale D, Gupta S, Ahnen DJ, et al. NCCN Guidelines Insights: Colorectal Cancer Screening, Version 1.2018. J Natl Compr Canc Netw. 2018;16(8):939-949.

2. Türkiye Cumhuriyeti Sağlık Bakanlığı Halk Sağlığı Genel Müdürlüğü. Kalın Bağırsak Kanseri (Kolorektal Kanser) https://hsgm.saglik.gov.tr/tr/haberler/kal\%C4\%B1n-

ba\%C4\%9F\%C4\%B1rsak-kanseri-kolorektal-kanser.html. 10 Eylül 2020'de erişildi.

3. Nam S, Kim D, Jung K, Choi YJ, Kang JG. Analysis of the incidence and clinical features of colorectal nonadenocarcinoma in Korea: A National Cancer Registry-based study [published online ahead of print, 2020 May 15]. Ann Coloproctol. 2020;10.3393/ac.2020.05.03.

4. Haggar FA, Boushey RP. Colorectal cancer epidemiology: incidence, mortality, survival, and risk factors. Clin Colon Rectal Surg. 2009;22(4):191-197.

5. Bray F, Ferlay J, Soerjomataram I, Siegel RL, Torre LA, Jemal A. Global cancer statistics 2018: GLOBOCAN estimates of incidence and mortality worldwide for 36 cancers in 185 countries [published correction appears in CA Cancer J Clin. 2020 Jul;70(4):313]. CA Cancer J Clin. 2018;68(6):394-424.

6. Weitz J, Koch M, Debus J, Höhler T, Galle PR, Büchler MW. Colorectal cancer. Lancet. 2005;365(9454):153-165.

7. Firth MJ, Sharples KJ, Hinder VA, et al. Methods of a national colorectal cancer cohort study: the PIPER Project. N Z Med J. 2016;129(1440):25-36

8. Çalışkan C, Akgün E, Doğanavşargil B, Korkut MA. Rare tumors mimicking colorectal carcinomas. Ege Journal of Medicine 2009;48:101-107.

9. Ellis L, Shale MJ, Coleman MP. Carcinoid tumors of the gastrointestinal tract: trends in incidence in England since 1971. Am J Gastroenterol. 2010;105(12):2563-2569.

10. Kang H, O'Connell JB, Leonardi MJ, Maggard MA, McGory $\mathrm{ML}$, Ko CY. Rare tumors of the colon and rectum: a national review. Int J Colorectal Dis. 2007;22(2):183-189.

11. Maryański J, Cyran-Chlebicka A, Szczepankiewicz B, Cebulski W, Słodkowski M, Wroński M. Surgical treatment of extraappendiceal colorectal neuroendocrine tumors. Pol Przegl Chir. 2018;90(3):7-12.

12. Smith JD, Reidy DL, Goodman KA, Shia J, Nash GM. A retrospective review of 126 high-grade neuroendocrine carcinomas of the colon and rectum. Ann Surg Oncol. 2014;21(9):2956-2962.

13. Al Natour RH, Saund MS, Sanchez VM, et al. Tumor size and depth predict rate of lymph node metastasis in colon carcinoids and can be used to select patients for endoscopic resection. J Gastrointest Surg. 2012;16(3):595-602.

14. Gay ND, Chen A, Okada CY. Colorectal Lymphoma: A Review.
Clin Colon Rectal Surg. 2018;31(5):309-316.

15. Iwamuro M, Okada H, Takata K, et al. Colorectal Manifestation of Follicular Lymphoma. Intern Med. 2016;55(1):1-8.

16. Jaime-Andrade $E$, Lino-Silva LS, Salcedo-Hernández RA, Zepeda-Najar C. Colorectal lymphoma in Mexico: clinicopathological and survival analysis. J Gastrointest Oncol. 2018;9(1):90-95

17. Ünal N, Coşgun G, Korkut M, et al. Ege Üniversitesi Tıp Fakültesi veri tabanındaki kolorektal kanserli olguların epidemiyolojik ve genel sağ kalım özellikleri. Ege Tıp Dergisi.2019;68-77.

18. Atak I. Anorectal Malignant Melanoma: Retrospective Analysis of Six Patients and Review of the Literature. Prague Med Rep. 2018;119(2-3):97-106.

19. Jeong HK, Cho SB, Seo TJ, et al. Autoamputation of a giant colonic lipoma. Gut Liver. 2011;5(3):380-382.

20. Bohlok A, El Khoury M, Bormans A, et al. Schwannoma of the colon and rectum: a systematic literature review. World J Surg Oncol. 2018;16(1):125.

21. Sarofim M, Attwell-Heap A, Trautman J, Kwok A, Still A. Unusual case of acute large bowel obstruction: endometriosis mimicking sigmoid malignancy. ANZ J Surg. 2019;89(11):E542E543.

22. Ishii $M$, Yamamoto $M$, Tanaka $K$, et al. Intestinal endometriosis combined with colorectal cancer: a case series. J Med Case Rep. 2018;12(1):21.

23. Take I, Shi Q, Qi ZP, et al. Endoscopic resection of colorectal granular cell tumors. World J Gastroenterol. 2015;21(48):1354213547.

24. Huh JW, Oh BR, Kim HR, Kim YJ. Preoperative carcinoembryonic antigen level as an independent prognostic factor in potentially curative colon cancer. J Surg Oncol. 2010;101(5):396-400. 